\title{
20. INTEGRATION OF VERTICAL SEISMIC PROFILING, LOGGING, AND SEISMIC DATA IN THE VICINITY OF THE DÉCOLLEMENT, NORTHERN BARBADOS RIDGE ACCRETIONARY PRISM ${ }^{1}$
}

\author{
G.F. Moore, ${ }^{2}$ Z. Zhao ${ }^{2}$ and T.H. Shipley ${ }^{3}$
}

\begin{abstract}
Vertical seismic profiling (VSP) and downhole logging carried out on Ocean Drilling Program Leg 156 provide ties to the regional three-dimensional seismic reflection data as well as velocity data near the décollement. Two thin, low-density, highporosity zones appear on logs within the décollement zone at Site 948, but the seismic signature of the zone is positive. The low-density zones are shown to be below the resolution of surface seismic data. The low-density zones therefore must increase in thickness along strike to yield the typical negative-polarity seismic signature of the décollement. The VSPs document the location the screened sections of casing at Sites 948 and 949 and confirm that they were emplaced over the décollement zone. VSP velocities measured in the accretionary prism above the décollement zone are higher than well-logging sonic velocities through the same section.
\end{abstract}

\section{INTRODUCTION}

Intriguing reversed-polarity fault-plane reflections are often observed on seismic reflection profiles across the toes of subduction zones (e.g., Costa Rica, Shipley and Moore, 1986; Nankai, Moore et al., 1990; Barbados, Westbrook, 1991; Shipley et al., 1994). These reversed-polarity reflections are believed to be generated by zones of anomalously low density due to elevated fluid pressures caused by focused fluid flow. Few in situ measurements have been made, however, to calibrate the seismic response of such faults.

One of the objectives of Leg 156 was to determine the nature of the décollement reflection observed in a regional three-dimensional seismic reflection data set across the toe of the Barbados accretionary prism (Shipley et al., 1994). Cores from the Barbados prism were collected for structural, geochemical, and physical properties measurements, geophysical logs were collected to provide in situ measurements of physical properties, and CORK experiments were conducted.

It is inherently difficult to tie surface seismic reflection data to core and logging data collected at Ocean Drilling Program (ODP) sites because the seismic data are collected in terms of two-way traveltime, whereas core and logging data are collected in terms of depth. Although the seismic data set was converted from time to depth, our knowledge of the velocity structure of the drilled section is imperfect, making the depth conversion imprecise. In addition, the exact location of the screened section of casing for the CORK experiments at Sites 948 and 949 relative to the seismic location of the décollement was not precisely known. For these reasons, we collected vertical seismic profiles (VSPs), which can provide a better tie between the seismic data and the logging/CORK data, because VSPs are collected in terms of depth downhole and traveltime. This traveltime vs. depth relationship also produces a profile of seismic velocity vs. depth at the borehole. In a zero-offset VSP, the seismic wavefield generated by a source at the surface directly above the hole is recorded by a seismometer clamped in the borehole at different depths (Gal'perin, 1974; Balch and Lee, 1984; Hardage, 1983).

${ }^{1}$ Shipley, T.H., Ogawa, Y., Blum, P., and Bahr, J.M. (Eds.), 1997. Proc. ODP, Sci. Results. 156: College Station. TX (Ocean Drilling Program).

${ }^{2}$ Department of Geology and Geophysics, University of Hawaii, Honolulu, HI 96822, U.S.A. gmoore@ hawaii.edu ${ }^{3}$ Institute for Geophysics, University of Texas at Austin, Austin, TX 78759-8345,
U.S.A.
We collected VSPs near the décollement zone at two sites on Leg 156. We also collected sonic and density data during downhole logging at these sites. In this paper, we use these VSP and logging data to document the depths and seismic character of the décollement zone.

\section{DATA ACQUISITION AND PROCESSING}

\section{Zero-offset Vertical Seismic Profiles}

We collected zero-offset VSPs at Sites 948 (97-470.3 mbsf) and 949 (39.1-397.25 mbsf). The experiments were planned to be run in two parts: the first part in the upper casing before installing the screened sections and the second part in the lower section below the screen. Time constraints precluded running a VSP in the lower part of the casing at Site 948, and the shuttle apparently became tangled at the casing during the second part of the experiment at Site 949. Receiver locations therefore are restricted to the region above the décollement at both sites.

The energy source for the VSPs was an array of two Bolt 1500-C air guns (4.9- and 2.0-L; 300 and $120 \mathrm{in}^{3}$ ) suspended $7 \mathrm{~m}$ below the sea surface from a buoy. A hydrophone suspended between the two air guns was used to determine the shot-firing times. The relative timing of the two guns was controlled by the Schlumberger MAXIS system. A second hydrophone suspended approximately $100 \mathrm{~m}$ below the surface was used to record the air-gun waveform for each shot. Seven to fifteen shots were fired at each clamping level to allow summing to increase signal-to-noise levels.

We used the Schlumberger Array Seismic Imager (ASI) to receive the seismic shots. The ASI consists of an array of five seismic shuttles, each containing three orthogonal geophone accelerometers. The shuttles are spaced at $15.24-\mathrm{m}(50 \mathrm{ft})$ intervals and are linked by a bridle to a signal-conditioning cartridge. The shuttles clamp magnetically to the casing. The ASI was moved uphole to yield geophone clamping levels at 7.62-m ( $25 \mathrm{ft})$ intervals. The signals received by the ASI were recorded in digital log interchange standard (DLIS) format on 4-mm (DAT) tape with the Schlumberger MAXIS system. Four seconds of 1-ms data were recorded for each shot. See Shipboard Scientific Party (1995) for additional details about the VSP acquisition.

The zero-offset VSP data were processed to reduce noise and to separate the upgoing and downgoing wavefields (Table 1; Figs. 1, 2). 
Table 1. Processing steps applied to VSP data.

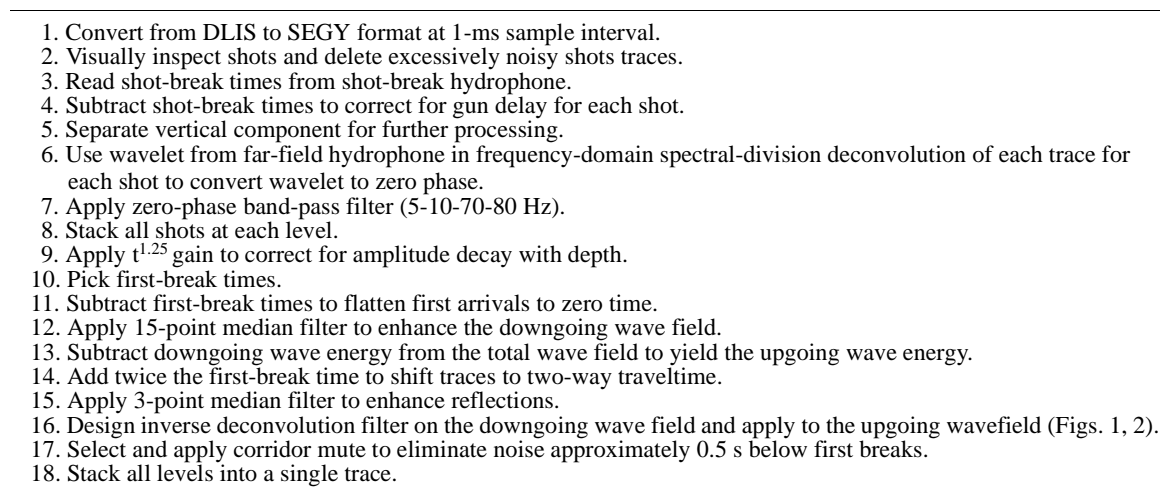

Figure 1. VSP collected in Hole 948D converted to two-way traveltime showing that the décollement is just below the depth of the deepest VSP receiver (470 mbsf). Solid bars indicate the location of the screened casing section in depth (top; 480.7-522.6 mbsf) and two-way traveltime (Screen).

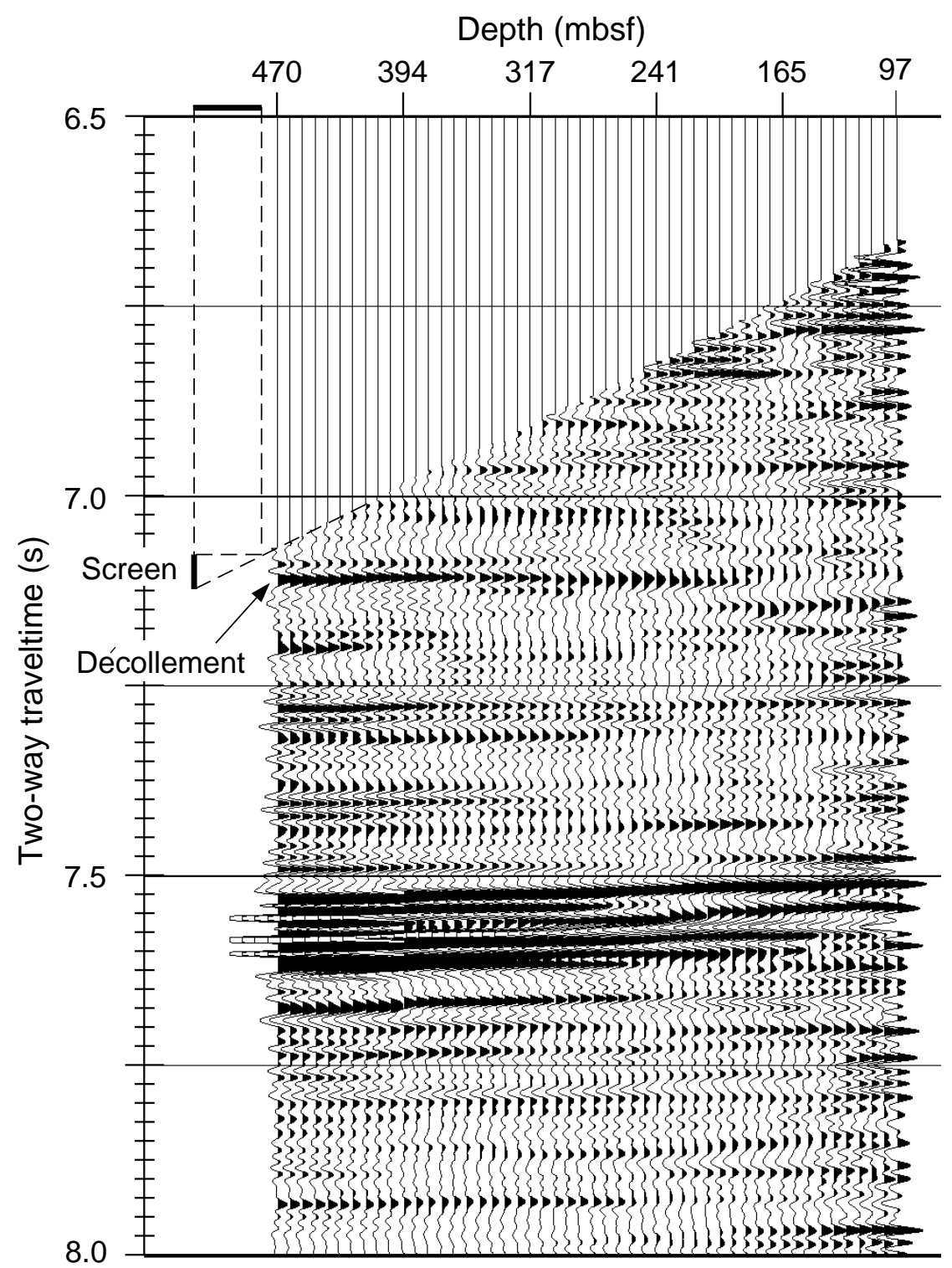


We followed standard processing procedures (e.g., Balch and Lee, 1984; Hardage, 1983).

\section{Velocity Analysis}

The first arrival on a VSP trace is a wave traveling at the compressional-wave velocity of the formation, so the first-break times from the VSPs provide a time-depth profile for the sampled interval. It is important to pick these times as consistently and accurately as possible. Because it is easier to pick a trough on the VSP traces rather than the onset of energy, we first converted the data to zero-phase with a trough at the true first-break location (Dillon and Collyer, 1985). We started with the signature-deconvolved data after step 6 (Table 1), stacked the traces for each level (without filtering), and then applied zero-phase spiking deconvolution and a zero-phase filter. First-break times were picked to a precision of $0.5 \mathrm{~ms}$ and plotted vs. depth (Figs. 3A, 4A). Velocities were determined by fitting line segments to the data points via least-squares linear regression. Line segments were chosen iteratively to yield the highest regression goodness-of-fit statistic $\left(\mathrm{R}^{2}\right)$. We show only those segments with very high quality regressions $\left(\mathrm{R}^{2}>0.995\right)$. Segments with poorer quality (in the upper sections of the holes) are not plotted in Figures 3A and 4A. We note that the first arrival times could be in error by $\pm 0.5 \mathrm{~ms}$ because of inaccuracies in picking first break times on both the shot-break hydrophone and the VSP traces. The potential for error is much greater at shallower depths because of poor coupling between the casing and the borehole wall, which leads to lower signal-to-noise ratios. Additional errors result from inaccuracies in our knowledge of the individual geophone depths (estimated to be $\pm 0.5 \mathrm{~m}$ ). We estimate the total errors in this analysis to be $\pm 2 \%-3 \%(35-60 \mathrm{~m} / \mathrm{s})$.

The interval velocities derived above are plotted in Figures 3B and 4B along with "instantaneous" velocities calculated from the time-depth differences between adjacent measurements and the wireline sonic velocities. These plots show that there is a velocity inver-

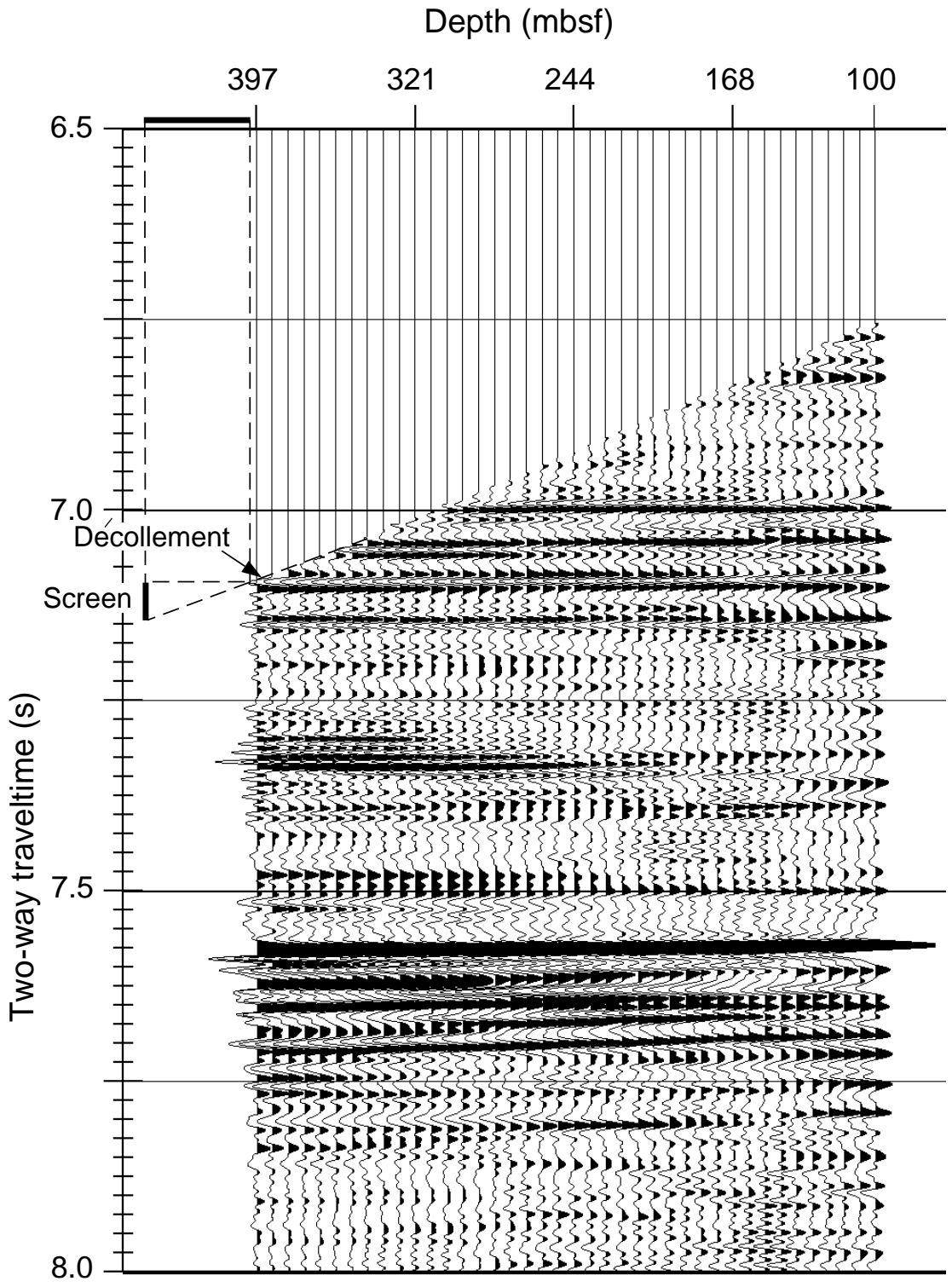

Figure 2. Processed VSP collected in Hole 949C showing that the deepest receiver (397 mbsf) was at the level of the décollement. Solid bars indicate the location of the screened casing section in depth (top; 398.0-450.0 mbsf) and two-way traveltime (Screen). 
Figure 3. A. Traveltime vs. depth of first breaks selected from the VSP at Site 948. Solid lines with labels show least-squares fit used to determine velocities. Dashed line shows traveltime (one-way) vs. depth determined by integrating sonic velocities from well $\log$ in Hole 948C. B. Sonic velocities from well log plotted with VSP instantaneous and interval velocities obtained from A.
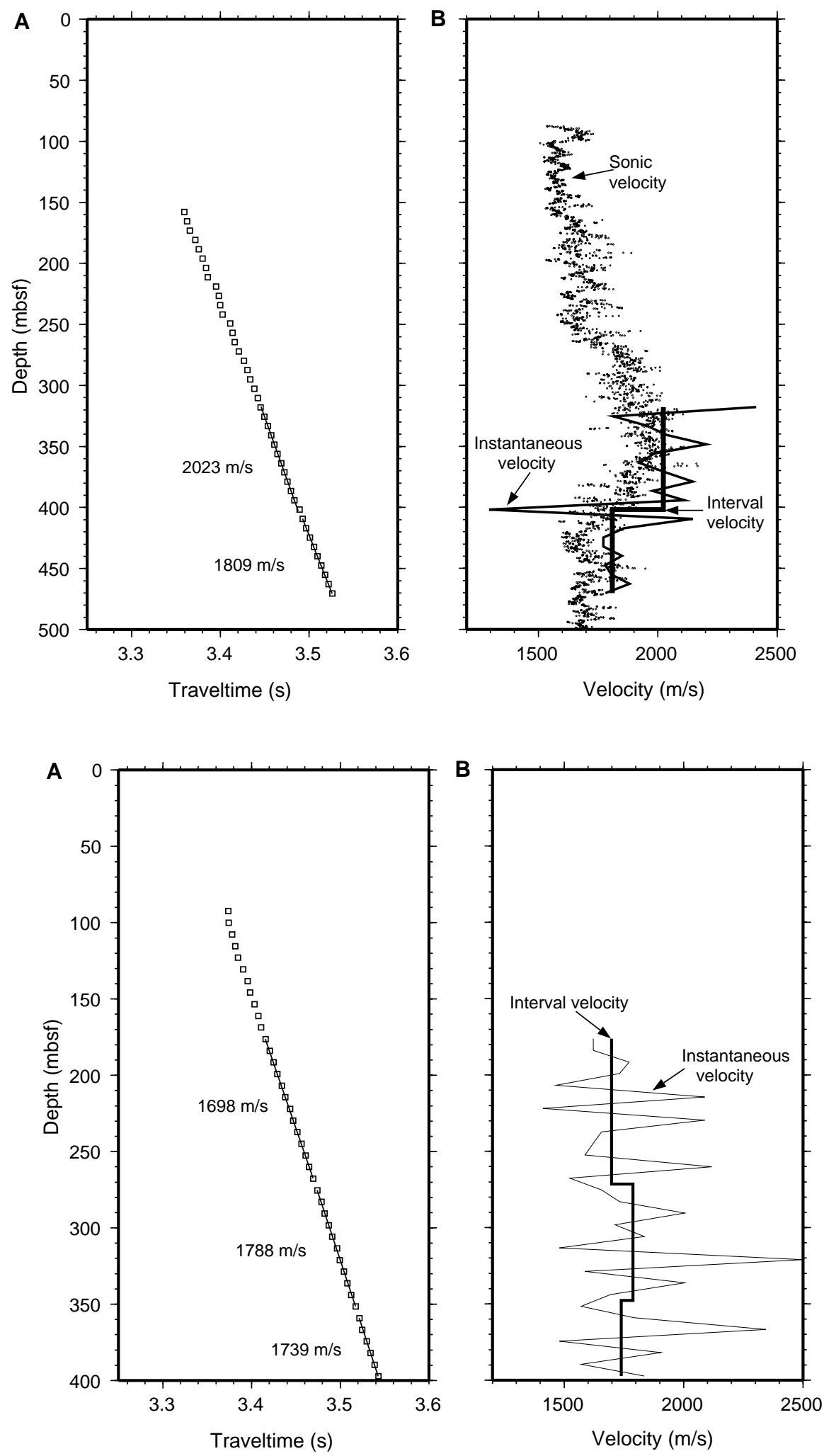

Figure 4. A. Traveltime vs. depth of first breaks selected from the VSP at Site 949. Lines show leastsquares fit used to determine velocities. B. Instantaneous and interval velocities obtained from $\mathrm{A}$. 
A

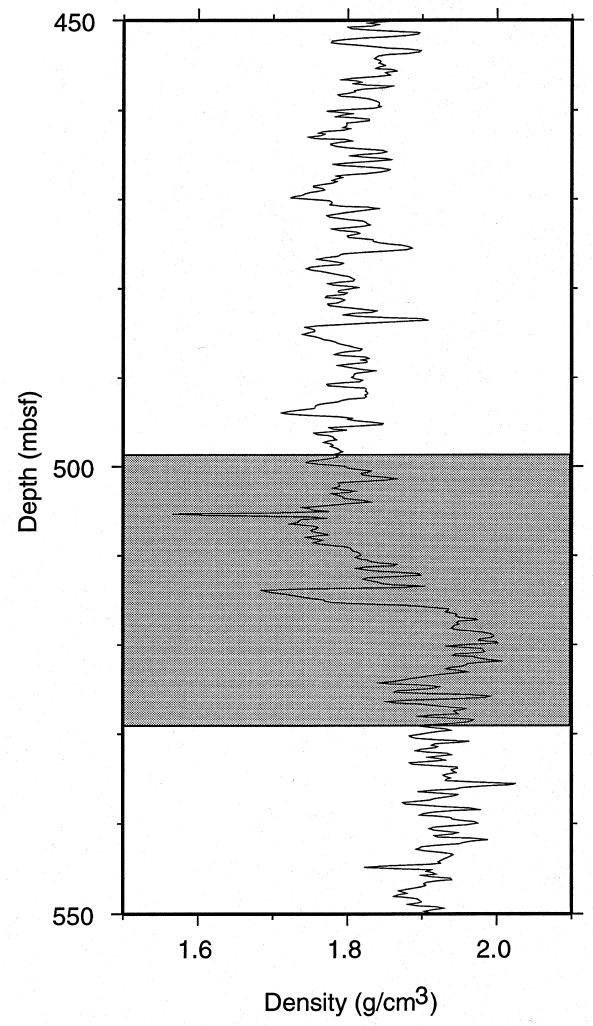

B

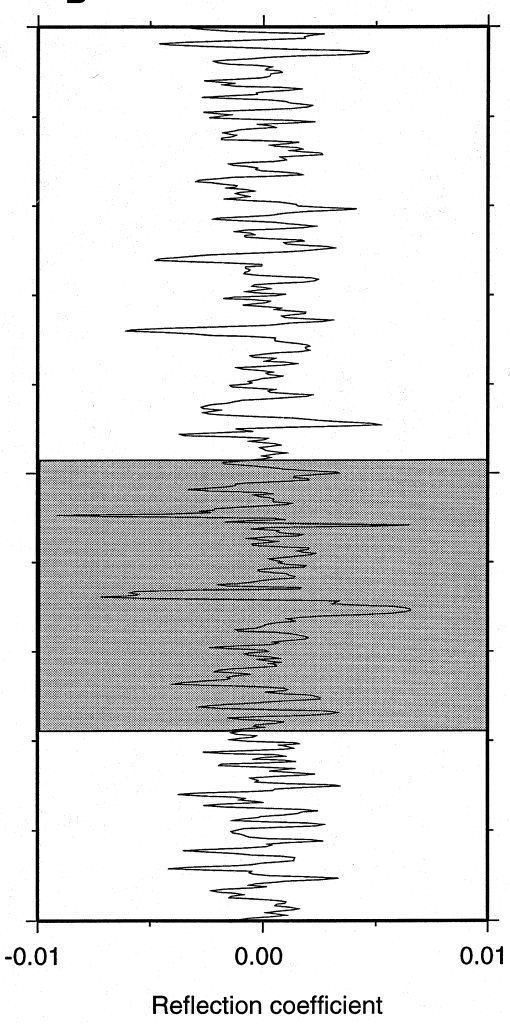

C

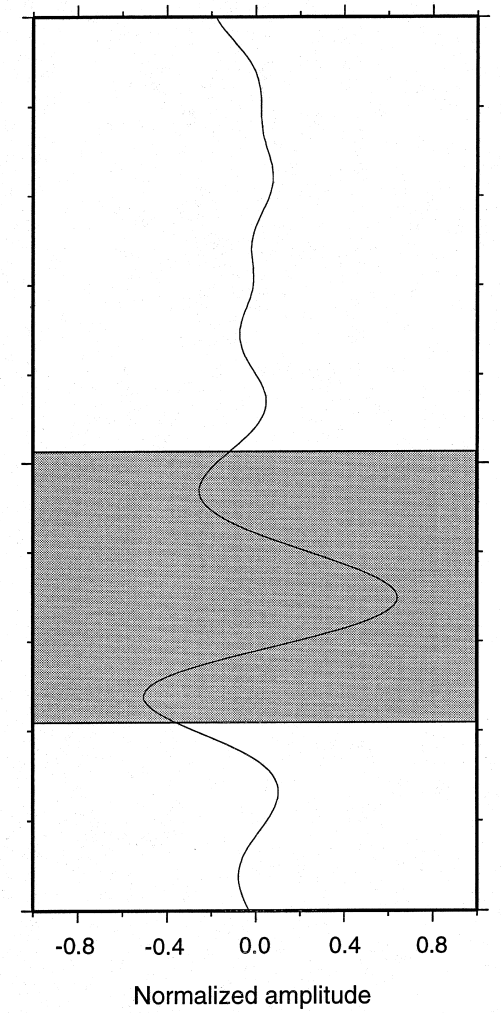

Figure 5. A. LWD density log from Site 948. Décollement zone is shaded. Note thin low-density zones at 505 and 514 mbsf and large density increase at $515-$ 516 mbsf. B. Reflection coefficient calculated from LWD density log and constant velocity with check-shot correction. Note large positive reflection coefficient at 515 mbsf. C. Synthetic seismogram created by convolving signature of three-dimensional seismic source with B.

sion about 100-200 $\mathrm{m}$ above the décollement zone at both Sites 948 and 949. This inversion is most apparent at Site 948 where the interval velocity drops from 2023 to $1809 \mathrm{~m} / \mathrm{s}$ with a single low-velocity spike at $402-403$ mbsf. The inversion is less dramatic at Site 949 , but it is still observable on both the large-scale interval velocity and instantaneous velocity curves. The large negative spike in the instantaneous interval velocity curve at $\sim 402$ mbsf at Site 948 is likely caused by errors in the location of the VSP receiver.

\section{Logging Data}

Logging-while-drilling (LWD) was carried out at Sites 947 and 948, and standard wireline logs were collected at Site 948. Resistivity and density data were collected during LWD operations, and sonic data were collected during wireline logging (Shipboard Scientific Party, 1995).

We generated acoustic impedance logs from the LWD density log and a constant velocity with check-shot correction using the VSP time-depth function (Fig. 5B). The impedance logs were convolved with the source wavelet extracted from the three-dimensional seismic data set, as described by Shipley et al. (1994), to yield a synthetic seismogram (Fig. 5C). We also generated a synthetic seismogram for Site 948 by using the wireline sonic data. Comparisons of the resulting synthetic seismograms to the three-dimensional seismic data showed a poor match near the décollement for the Site 948 seismogram calculated with the wireline sonic data. This is likely because of degradation of the sonic data by poor borehole conditions. Therefore, we did not use the seismogram based on the sonic log in the analysis below.

\section{Comparison of Vertical Seismic Profiling and Log Data to Regional Seismic Reflection Data}

The stacked zero-offset VSP data should be directly comparable to the regional multichannel seismic data. Figure 6 shows duplicated traces of the stacked VSP at Site 948 compared to three-dimensional seismic reflection Line 681 . The prominent reflection at $7.1 \mathrm{~s}$ is the décollement zone, as identified on Figure 1. The depth of the décollement reflection is deeper than the deepest VSP clamping location (470 mbsf). Figure 7 shows the synthetic seismogram at Site 948 compared to seismic Line 688 . The décollement reflection in the synthetic seismogram matches the décollement in the three-dimensional seismic data. Both reflections are asymmetric positive reflections, with the lower negative lobe having higher amplitude than the upper negative lobe. The wavelength of the reflection on both the synthetic and three-dimensional traces is the same. We note that neither the synthetic seismogram nor the stacked VSP match particularly well with the three-dimensional seismic data in the accretionary prism, primarily because of the overall low amplitudes of the prism reflections.

The VSP at Site 949 is compared to seismic Line 737 in Figure 8. The décollement is confirmed to be at a time of $7.1 \mathrm{~s}$, as shown on the VSP (Fig. 2). This reflection is at about the depth of the deepest VSP clamping location (397 mbsf). Two other prominent reverse-polarity reflections are seen on the VSP, one above the décollement at $7.05 \mathrm{~s}$ ( $351.5 \mathrm{mbsf}$ ) and one below the décollement at $7.15 \mathrm{~s}$. The lower reflection is the proto-décollement (Horizon "A"; Moore, Zhao, et al., 1995) at a depth of about 450 mbsf. 
Figure 6. Stacked VSP at Site 948 inserted into threedimensional seismic Line 681 showing excellent match of décollement reflection.
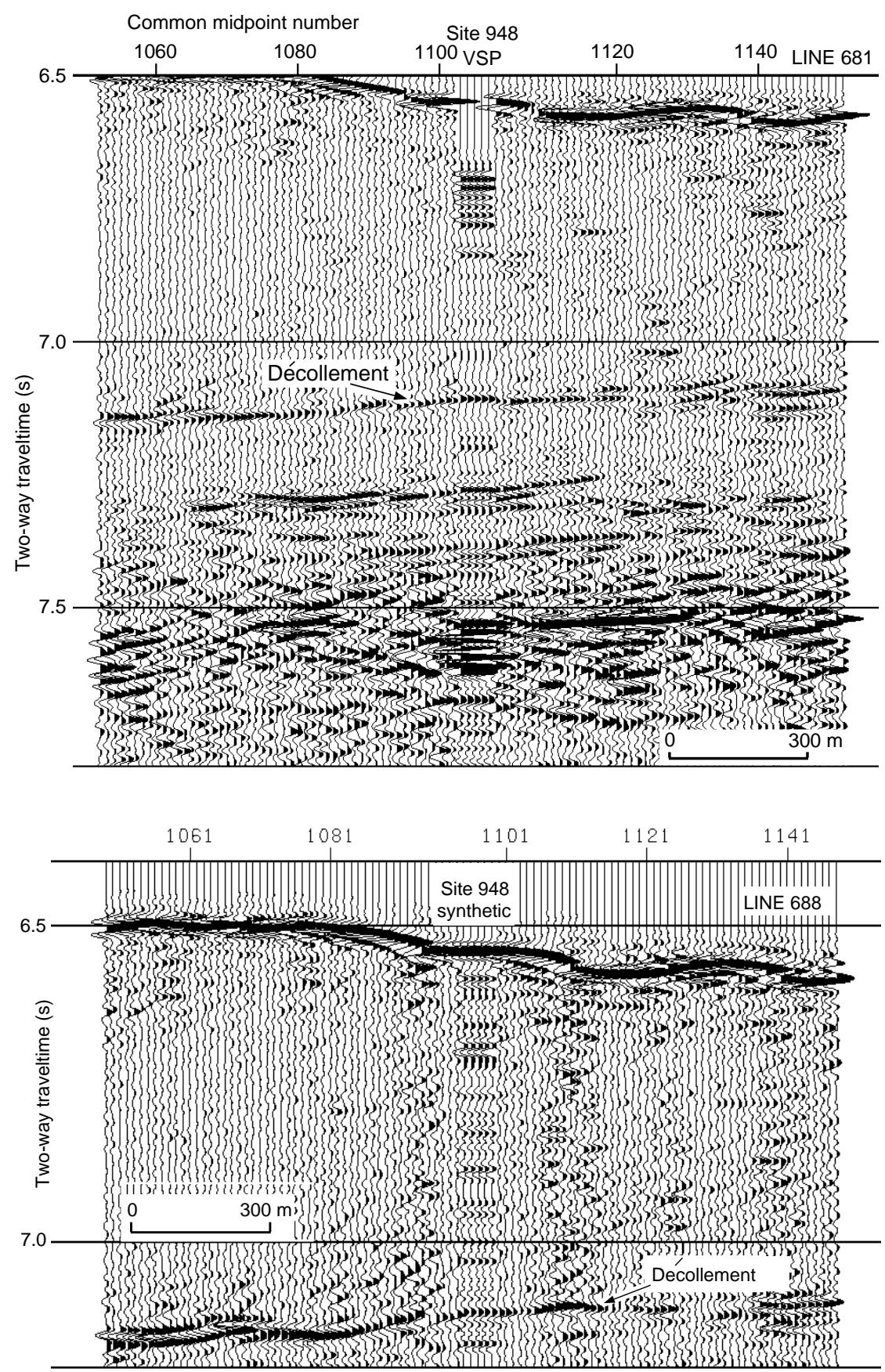

Figure 7. Synthetic seismogram made from LWD density data at Site 948 inserted into three dimensional seismic Line 688 showing close match of décollement signature.

\section{DISCUSSION}

\section{Location of Screened Sections of Casing at Sites 948 and 949}

The screened sections of the casing in Holes 948D and 949C relative to the décollement reflection are precisely located via the VSPs collected in those holes. Figures 1 and 2 show the measured depths of the screened sections plotted as solid bars along the depth axis. These depth intervals are carried down the two-way traveltime axis to their intersection with the extrapolated position of the VSP first-break line to yield the location of the screened section in time. The screened section at Site 948 straddles the seismic décollement reflection, and the screened section at Site 949 starts at approximately the top of the décollement reflection and extends below it.
The décollement at the base of the northern Barbados accretionary prism is imaged as a distinct reflection that is typically reversed in polarity with respect to the seafloor reflection (Fig. 8; Bangs and Westbrook, 1991). The décollement zone was a primary target for Leg 156 drilling, so local variations in the décollement amplitude around the drill sites are significant. The most important décollement amplitude variation with respect to the Leg 156 drill sites is the change from reversed polarity at Site 949 to normal polarity (same as the seafloor reflection) at Site 948 (Figs. 6, 7). Although drilling and logging operations sought to determine the physical properties differences between the normal and reversed polarity regions, we were hampered 


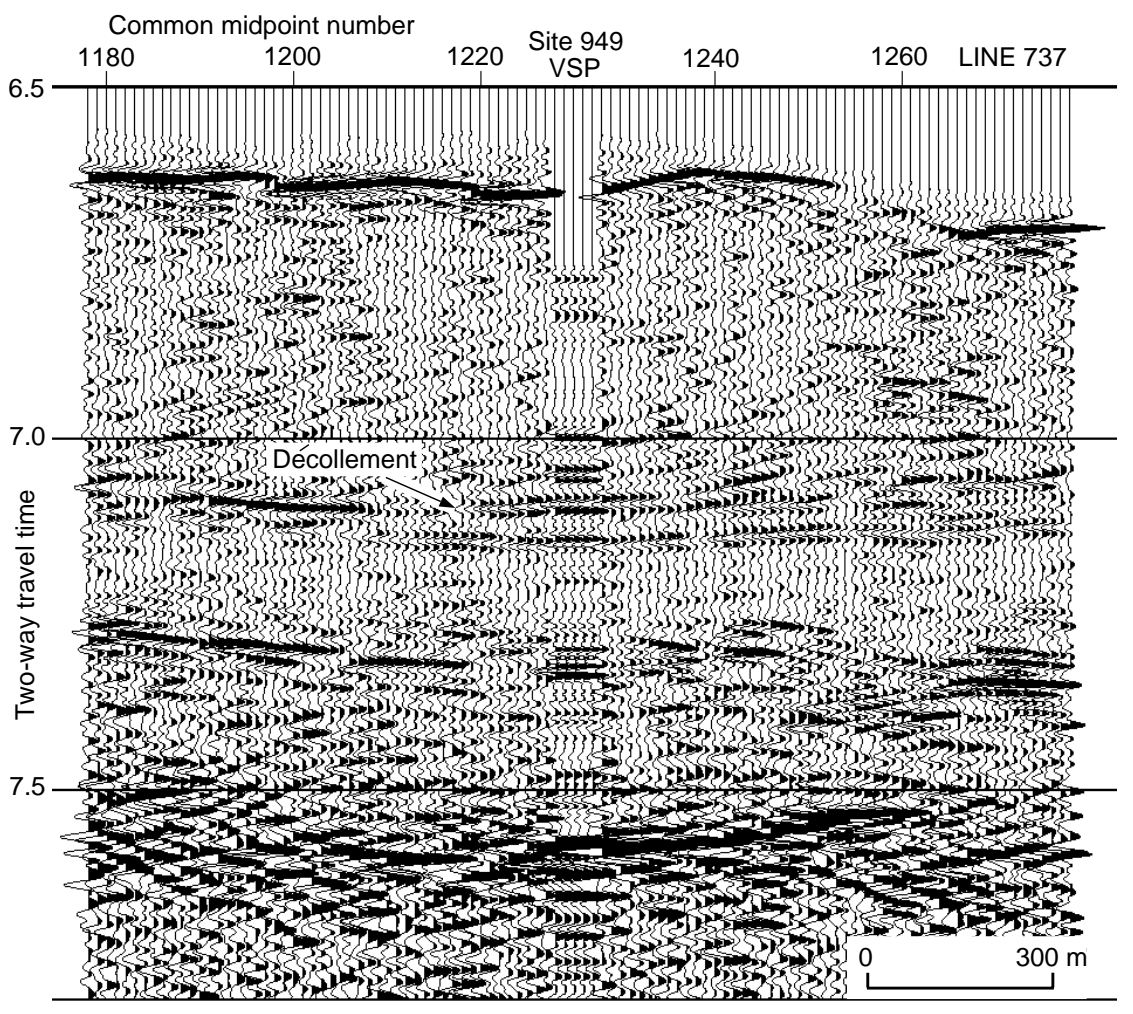

Figure 8. Stacked VSP at Site 949 inserted into threedimensional seismic Line 737 showing tie between VSP data and décollement on seismic line. in this attempt at Site 949 by poor core recovery, lack of downhole logging data, and mechanical problems with the VSP. We have therefore attempted to compare the positive and negative décollement reflection through synthetic seismic modeling. Variations in amplitude of the décollement reflection were discussed by Shipley et al. (1994), whose preliminary seismic modeling attributed the reversed polarities to a relatively thin fault zone $(\sim 14 \mathrm{~m})$, with lower acoustic impedance (velocity times density) than the surrounding material. Further modeling by Bangs et al. (1996) confirmed that the negative reflection is caused by a low-velocity interval $12-16 \mathrm{~m}$ thick.

Our synthetic seismogram (Fig. 7) is based on the LWD density $\log$ and constant velocity (with VSP time-depth correction), so the reflection character of the décollement is generated by the density variations only. Although there are two sharp, low-density spikes at 505 mbsf and 514 mbsf, there is a much larger density increase at 515516 mbsf (Fig. 5A). The low-density spikes generate narrow negative reflection coefficients, whereas the larger density increase produces a wider, higher-amplitude positive reflection coefficient (Fig. 5B). The resulting seismic signature of the décollement is therefore a positive reflection (Fig. 5C). Thus, the areas where the décollement is imaged as strong negative-polarity reflections must represent regions with thick overpressured layers. These layers are much thinner than the structurally defined décollement, indicating that fluid pathways are likely continuous, but may vary considerably in thickness.

Velocity inversions in the section just above the décollement zone are documented at Sites 948 and 949. These inversions correlate with density inversions that are interpreted as regions of moderately abnormal fluid pressures (Moore, Shipley, et al., 1995). These zones of high fluid pressure above the décollement may be regionally significant and may affect the overall décollement seismic signature (Shipley et al., Chapter 23, this volume).

We note that the interval velocities derived from the VSP at Site 948 are generally higher than the sonic velocities. Differences in the two data sets can be partially attributed to the difference in frequency of the sources (tens of $\mathrm{Hz}$ for the VSP, thousands of $\mathrm{Hz}$ for the sonic data). Damage to the formation adjacent to the borehole might also result in lower sonic velocities because the sonic tool senses a much shorter distance into the formation than does the VSP. The traveltime vs. depth curve derived by integrating the wireline sonic velocities is plotted in Figure 3A. If the VSP data were not available, the tie between the borehole observations and the three-dimensional seismic data would have to rely on the integrated sonic curve. It is apparent that the integrated sonic yields traveltimes are as much as $0.02 \mathrm{~s} \mathrm{high-}$ er than traveltimes for the VSP, because the sonic velocities are lower than the VSP velocities.

\section{CONCLUSIONS}

Vertical seismic profiles at two sites in the Barbados accretionary prism provide an excellent tie between the regional three-dimensional seismic reflection data set and the drilled section at Sites 948 and 949. Ties made using the integrated sonic data at Site 948 would be in error, because sonic velocities are lower than the VSP velocities. The VSP velocities are likely to be more representative of the seismic velocities of the drilled section. The VSPs also demonstrate that the screened sections of casing at Sites 948 and 949 are across the décollement zone and document interval velocity inversions within 100-200 $\mathrm{m}$ above décollement. Two thin sections of reduced density within the décollement zone at Site 948, interpreted to be zones of overpressure (Moore, Shipley, et al., 1995), are not resolved by the seismic systems used to collect VSPs nor the three-dimensional seismic data set. A synthetic seismogram calculated from the LWD densities confirms that the zones are too thin to generate a negative-polarity reflection, so the low-density, high fluid pressure zones that generate a negativepolarity reflection in other parts of the Barbados prism must be several meters thick. 


\section{ACKNOWLEDGMENTS}

A thorough review by T.J. Henstock greatly improved the manuscript. This research was supported by JOI/USSAC. SOEST contribution number 4506. UTIG contribution number 1282.

\section{REFERENCES}

Balch, A.H., and Lee, M.W., 1984. Vertical Seismic Profiling: Technique, Applications, and Case Histories: Boston (Int. Human Resour. Develop. Corp.).

Bangs, N.L., Shipley, T.H., and Moore, G.F., 1996. Elevated fluid pressure and fault zone dilation inferred from seismic models of the northern Barbados Ridge decollement. J. Geophys. Res., 101: 627-642.

Bangs, N.L., and Westbrook, G.K., 1991. Seismic modeling of the décollement zone at the base of the Barbados Ridge accretionary complex. $J$. Geophys. Res., 96:3853-3866.

Dillon, P.B., and Collyer, V.A., 1985. On timing the VSP first arrival. Geophys. Prosp., 33: 1174-1194.

Gal'perin, E.I., 1974. Vertical seismic profiling. SEG Spec. Publ. 12: Tulsa, OK (Soc. Expl. Geophys.).

Hardage, B.A., 1983. Vertical Seismic Profiling, Part A: Principles: London (Geophysical Press).

Moore, G.F., Shipley, T.H., Stoffa, P.L., Karig, D.E., Taira, A., Kuramoto, S., Tokuyama, H., and Suyehiro, K., 1990. Structure of the Nankai Trough accretionary zone from multichannel seismic reflection data. J. Geophys. Res., 95:8753-8765.

Moore, J.C., Shipley, T.H., Goldberg, D., Ogawa, Y., Filice, F., Fisher, A., Jurado, M.-J., Moore, G.F., Rabaute, A., Yin, H., Zwart, G., Brückmann,
W., Henry, P., Ashi, J., Blum, P., Meyer, A., Housen, B., Kastner, M., Labaume, P., Laier, T., Leitch, E.C., Maltman, A.J., Peacock, S., Steiger, T.H., Tobin, H.J., Underwood, M.B., Xu, Y., and Zheng, Y., 1995. Abnormal fluid pressures and fault-zone dilation in the Barbados accretionary prism: evidence from logging while drilling. Geology, 23:605-608.

Moore, G.F., Zhao, Z., Shipley, T.H., Bangs, N., and Moore, J.C., 1995. Structural setting of the Leg 156 area, northern Barbados Ridge accretionary prism. In Shipley, T.H., Ogawa, Y., Blum, P., et al., Proc. ODP, Init. Repts., 156: College Station, TX (Ocean Drilling Program), 13-27.

Shipboard Scientific Party, 1995. Explanatory notes. In Shipley, T.H., Ogawa, Y., Blum, P., et al., Proc. ODP, Init. Repts., 156: College Station, TX (Ocean Drilling Program), 39-68.

Shipley, T.H. and Moore, G.F., 1986. Sediment accretion, subduction, and dewatering at the base of the trench slope off Costa Rica: A seismic reflection view of the décollement. J. Geophys. Res., 91:2019-2028.

Shipley, T.H., Moore, G.F., Bangs, N.L., Moore, J.C., and Stoffa, P.L., 1994. Seismically inferred dilatancy distribution, northern Barbados Ridge décollement: implications for fluid migration and fault strength. Geology, 22:411-414.

Westbrook, G.K., 1991. Geophysical evidence for the role of fluids in accretionary wedge tectonics. Phil Trans. R. Soc. Lond. A, 335:227-242.

Date of initial receipt: 1 February 1996

Date of acceptance: 9 October 1996

Ms 156SR-032 